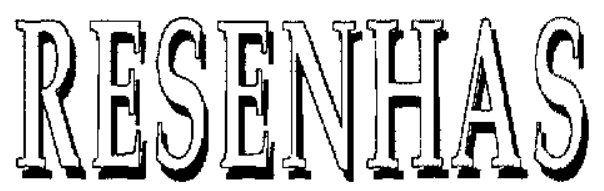

\section{FLEXIBILIDADE TOTAL, HOMEM X MÁQUINA}

MOURA, REINALdo A, Săo Paulo, IMAM, 1987, 141 págs.

\section{Por Kurt Ernst Well}

Protessor Titular do Departamento de

Administração da Produção e de

Operaçoes Industriais da EAESPIFGV.

Trata-se de um livro que, parcialmente, ainda denuncia sua origem: uma pesquisa secundária feita no curso de Pós-Graduação da Escola Politécnica da Universidade de Săo Paulo (EPUSP). Isso não desmerece o conteúdo, mas a forma e o estilo sofreram algo com as limitações impostas ao tempo dedicado à obra. Principalmente para quem tem o prazer de conhecer o autor como brithante pesquisador e consultor, faz falta a riqueza de experiências próprias dele.

Há falha no seqüenciamento. Por exemplo, "flexibilidade" só é definida na pág. 28, após muita discussão sobre tipos de flexibilidade. $\mathrm{E}$ a definiçăo - "a capacidade para tomar novas açöes para encontrar novas circunstâncias" - deveria incluir o que é falado uma linha abaixo: "... para responder a novas circunstâncias." Pequenos pontos como este cansam o leitor atento. Para a satisfaçăo do mesmo, temos observações sobre o tempo de inovação, que decresce constantemente. Só que "tempo de inovação" é o intervalo entre pesquisa pura (desinteressada) e o produto útil.

Após muitos anos de observação de flexibilidade, o resenhista concorda com as divisöes dadas pelo autor:

- Flexibilidade de homens (quanto à definição de cargos, falta o exemplo da Toyota, comparada à G.M.: a primeira, com duas a seis "descriçós de cargos" de operários; a segunda, com 50 a 100).
- Flexibilidade de máquinas - A troca de estampas ou de ferramentas em minutos e suas frações.

- Flexibilidade de linha - Para muitos produtos.

- Flexibilidade de carga - Para grande ou pequena quantidade, conforme o número de homens na linha.

Que uma divisão dessas leva o autor teoria e prática de células de trabalho é evidente, como também ao J.IT.T. e ao Kanban.

Como, infelizmente, a pesquisa usou fontes secundárias, salienta-se a divisăo de Zelenovic, que é a base, por assim dizer, do livro presente: a divisăo em fluxos discretos e contínuos da produção e "layout" de grupos de peças.

O resenhista lamenta a ausência de experiência japonesa do autor, só mencionada quase no fim do livro (págs. 125/27/28) e, principalmente, a falta de dados sobre a redução de "descriçōes de cargos" ("Job Descriptions") nos EUA, no Japão e no Brasil e a posiçäo dos sindicatos operários. Para exemplificar, no Japão, há operários de linha que fazem tudo, desde pintura até usinagem, enquanto que, nos EUA e no Brasil, há "pintor", "fresador", "torneiro", etc.

A importância disso na flexibilidade não pode ser negada.

Fora disso, temos os problemas de intensidade de emprego de capital para conseguir flexibilidade, chegando o autor a afirmar que a Toyota (Japão) tem ponto de equilíbrio de $30 \%$, o que significa quase ausência de custos fixos. Tive a idéia de quantificar a afirmação do autor, partindo da fórmula:

$$
\text { Pequ. }=\frac{F}{b-a} \quad \text { onde }
$$

Pequ $=$ Ponto equilibrio em unidades

$F=$ Custos Fixos totais em $\$$

b - $\mathbf{a}=$ Margem unitária de contribuição em $\$$

Então, dividíndo-se Pequ. por PCAP = Produçäo no nível da capacidade em uni- 
dades de venda, temos:

$$
\frac{P \text { equ }}{P C A P}=\frac{F}{P C A P} \times \frac{1}{b-a}
$$

Como o autor afirma que o Pequ. da Toyota ê $30 \%$ da capacidade, temos:

$$
\begin{aligned}
& 0,3=\frac{F}{P C A P} \times \frac{1}{b-a}, \quad \text { donde } \\
& 0,30(b-a)=\frac{F}{P C A P} \text { o que significa que } 30 \%
\end{aligned}
$$

da margem de contribuiçăo unitária correspondem ao custo fixo por unidade na capacídade.

Tomando (por cima) um automóvel que tem o preço, sem imposto, de Cz $\$ 800.000,00$, e a usual participação de custo variável de $57 \%$ de material comprado e $23 \%$ de mãode-obra, teríamos $0,2 \times 800.000=\$ 160.000,00$ de margem de contribuição e corresponde a somente $6 \%(0,3 \times 0,2)$ de custos fixos. Uma comparação, feita pelo resenhista, com dados alemães, chegou a resultados similarmente baixos para os custos fixos $(40 \%$ de mão-de-obra, $50 \%$ de material comprado e $5 \%$ de custos fixos).

Nota-se aqui um ponto sobre flexibilidade que o autor pretende desenvolver futuramente, pois ensina-se que flexibilidade de máquinas e homens sai cara em custos fixos (investimentos).

O livro trata dos seguintes assuntos, conforme seu sumário (índice):

- Flexibilidade

- SFM - Sistemas Flexiveis de Manufatura

- FSE - Fabricação Sem Estoques

- Comparaçẫo no SFM vs FSE

Para quem tenha conhecimentos elementares de procedimentos japoneses, o livro começa a se tornar valioso a partir do conceito de flexibilidade na preparação de mắquinas (pág. 107). Em seguida, a partir da linha de produção em "U", das discussōes sobre "layout" (pág. 113) e célula (pág. 115), chega-se à conceituação da produção flexível (pág. 120) e a sua distínção da automaçăo (pág. 119). Nota-se que o autor está usando os seus profundos conhecimentos mais nesses capítulos finais - aliás, ele assina alguns gráficos com "autor".

Para todos, e repito, todos os envolvidos em processos produtivos, o livro tem alto valor, pois mostra procedimentos modernos, usados pelos atuais líderes de processos de produtividade - os japoneses. Os defeitos enumerados não pesam quando o livro é usado como introdução ao estudo da engenharia da fábrica. O livro, assim, deve ser usado em cursos de administração da produção e manufatura, em cursos de graduaçăo e pós-graduação de administraçăo, e como introdução em cursos de engenharia de produção. Não deve ser leitura única, pois exige conhecimentos prévios de engenharia industrial. Em treinamento de executivos, o livro pode ser considerado altamente valioso, combinado, evidentemente, com filmes e transparências.

Como sempre, faz falta um índice alfabético remissivo, que dá muito trabalho se feito manualmente, mas que, com um computador, leva pouco tempo.

\section{ECONOMIA AGRICOLA: O SETOR PRIMÁRIO E A EVOLUÇÃO DA ECONOMIA BRASILEIRA}

MARCOS CINTRA C. ALBUQUERQUE E ROBERT N. V. C. NICOL. , Sáo Paulo, McGraw-Hill, 1987.

\section{Por Solival Silva e Menezes}

Mestrando em Economia do IPEUSP e em Administração de Empresas da EAESP/FGV.

Esta obra, escrita por dois importantes economistas da Escola de Administraçäo de Empresas da Fundação Getúlio Vargas, representa uma importante contribuição para a compreensão do papel do setor primário e dos ciclos agrícolas na dinâmica da industrializaçăo brasileira.

Evitando a mera referếncia teórica, os autores estabelecem, já no capítulo inicial, um interessante painel que vincula o tema tratado à teoria existente sobre o assunto, destacando-se a menção às idéias de David Ricardo que, em seus The Principles..., inaugura a preocupação dos economistas em associar a questão agrícola aos problemas específicos do capitalismo industrial. Tratam, também, das idéias de economistas contemporâneos, como W. A. Lewis, J. C. Fei, G. Ranis, M. H. Watkins, J. Mellor e Hymes e Resnick.

A teoria rícardiana é examinada, tendo como referência năo apenas os originais desse clássico, mas também interpretações recentes, como as de Irma Adelman, Thweat e Barber. Verificam de perto as análises de J. Mellor na tentativa de mostrar o papel da agricultura no desenvolvimento e tratam de forma atenciosa o modelo de Lewis com oferta ilimitada de trabalho. Também expandem a análise de Lewis através do trabatho de Fei e Ranis, passando de uma agricultura de pequenos lavradores para uma economia de maior expressão capitalista, com assalariados e com um processo de acumulação consubstanciado na elevada propensão 